\title{
Г.А. Телегина
}

\section{ТЕОРЕТИЧЕСКИЕ ПОДХОДЫ К ОПРЕДЕЛЕНИЮ ПОНЯТИЯ «СОЦИАЛЬНОЕ СОПРОВОЖДЕНИЕ» В СОЦИОЛОГИИ}

\begin{abstract}
Анализируется понятие «социальное сопровождение» в контексте социологических концепций. В то же время нельзя не отметить, что потребность рассмотрения категории обусловлена и ее междисциплинарным статусом, поскольку активно эта дефиниция используется иными научными дисциплинами, такими как психология, педагогика и др. Вместе с тем данная проблематика находит свое отражение и в социологии, где зачастую социальное сопровождение связывают с изучением вопросов оказания социальной помощи индивидам и семьям, находящимся в трудной жизненной ситуации. На наш взгляд, категория «социальное сопровождение» с позиции социологии имеет гораздо более сложную структуру, собственно так же, как и смысловое значение. Мы рассмотрели ее сущность, опираясь на такие классические подходы в социологии, как системный, активистско-деятельностный, теорию социального конструирования и теорию обмена, проанализировав их с учетом современного контекста. В то же время были изучены работы иных исследователей. Разнообразие взглядов на понятие «социальное сопровождение» в научной социологической литературе позволяет выделить три типа взглядов: социальное сопровождение граждан в обществе; социальное сопровождение в системе оказания помощи отдельным категориям граждан или в конкретных жизненных условиях; социальное сопровождение индивида или семьи в организации. Нами проведен анализ содержания данной типологии и выделены следующие критериальные основания: системные характеристики, невозможность сведения только к технологии социальной помощи, специфика взаимодействия между сопровождающим и сопровождаемым, приобретение социального опыта в процессе сопровождения, преодоление эксклюзии и обеспечение доступа к ресурсам социальной системы.

Ключевые слова: социальное сопровождение, трудная жизненная ситуация, активистскодеятельностный подход, системный подход, теория социального конструкционизма, теория социального обмена.
\end{abstract}

Введение. В настоящее время отмечается активный интерес к вопросам усовершенствования системы социальной работы с различными категориями населения. Важным шагом в данном направлении стало внедрение в деятельность социальных служб практики социального сопровождения.

Решение проблем людей, попавших в трудную жизненную ситуацию, в настоящий момент не ограничивается лишь предоставлением гарантий и мер социального обеспечения, активной реабилитации, но и такой помощи, которая позволит индивиду или семье на структурном уровне взаимодействия чувствовать себя более уверенно и выступать в качестве функционально способного и активного субъекта. На наш взгляд, жизненные проблемы могут быть преодолены за счет таких подходов, где для индивидов или семей будут созда-

(C) Телегина Г.А., 2021

Телегина Галина Александровна - ст. преподаватель кафедры социальной работы и конфрликтологии ФГБОУ ВО «Пермский государственный национальный исследовательский университет», e-mail: teleginagln@yandex.ru. 
ны условия не только для восстановления социального статуса и внутренней структуры отношений, но и возможности для построения сбалансированных, партнерских и социально эффективных связей и взаимодействия в обществе.

Одним из перспективных подходов в этой связи нам представляется формирование системы социального сопровождения. Понятие «социальное сопровождение» стало широко применяться в контексте форм и технологий социальной работы с различными группами населения в России в связи с принятием Федерального закона «Об основах социального обслуживания граждан в Российской Федерации» от 28.12.2013 № 442-Ф3. Однако до принятия данного закона в социально-гуманитарной области исследований были сделаны существенные наработки по уточнению ключевых признаков данного понятия. Осложнило ситуацию то, что представители разных научных направлений используют достаточно узкое толкование дефиниции «сопровождение», что порождает ряд проблем в интерпретации не только этого понятия, но и категории «социальное сопровождение». Данная тенденция актуализирует необходимость уточнения содержания данного определения в контексте существующих теоретических взглядов и подходов. Социальное сопровождение как категория для научного осмысления стало рассматриваться недавно. По мнению ряда авторов, оно является междисциплинарным. Наравне с психологическим, педагогическим и социально-педагогическим подходами, сопровождение употребляется и в социологическом толковании, для решения задач научного обоснования вопросов теории социальной работы и развития социального обслуживания. Стоит отметить, что социологических исследований, посвященных вопросам социального сопровождения, в современной литературе представлено значительно меньше. В то же время актуальность социологического анализа данной категории подчеркивается современными исследователями.

Цель подготовки статьи заключается в проведении анализа теоретических подходов в социологии, на основе которых сегодня может быть рассмотрено социальное сопровождение.

Анализ актуальных научных исследований. Предваряя анализ социологических подходов, через призму которых можно рассматривать социальное сопровождение, следует отметить, что в современной литературе существует не только междисциплинарная неопределенность в исследовании и трактовке данного термина, но и различия в представлениях о том, на каком уровне и в каких масштабах реализуется социальное сопровождение. Так. например, Е.И. Холостова, на наш взгляд, достаточно широко рассматривает определение понятия «социальное сопровождение», отмечая, что оно представляет собой особый вид деятельности социальных служб и одновременно особый тип взаимодействия со специалистами социальной сферы. Однако стоит признать, что в данном случае автор не ограничивается представлением социального сопровождения лишь через деятельностный аспект, а отмечает очень важную 
сущность социального сопровождения, которая заключается в специфической системе взаимодействия, которая не сводится лишь к индивидуальному взаимодействию специалиста социальной службы и клиента. Раскрывая основные задачи, решаемые в процессе социального сопровождения, автор выделяет, с одной стороны, задачи типичные для системы социального обслуживания населения (адаптация, реабилитация, повышение социального статуса клиента, восстановление здоровья), а с другой - задачи, которые подразумевают оптимизацию взаимодействия между клиентом и обществом («нормализация отношений и утверждение себя в социуме»), а также те, которые ориентированы на повышение потенциала клиента в процессе сопровождения для его последующей успешной реализации в жизни («создание условий для самореализации клиента в семье и обществе») [1, с. 565-566].

Социальное сопровождение может быть рассмотрено в контексте деятельности отдельного учреждения или организации. Чаще всего авторы отмечают такие разновидности сопровождения, как социально-психологическое, социально-педагогическое и др. Кроме того, в рамках организации часто используется комплексное сопровождение, включающее в себя различные виды сопровождения. В том числе в этот перечень включают и социальное сопровождение, но его влияние ограничивается сферой и полномочиями деятельности конкретного учреждения или организации. Так, например, В.В. Сизикова и Н.А. Тюрина [2, с. 106], исследуя вопросы сопровождения студентов с инвалидностью в организации высшего образования определяют такие задачи социального сопровождения, как решение бытовых и транспортных проблем; предоставление необходимых медикаментов; помощь во включении в студенческое самоуправление, самодеятельность, научную работу, в организации досуга, летнего отдыха, культурных мероприятий, оздоровительных программ; оказание материальной поддержки при определенных жизненных ситуациях. Таким образом, в данном случае мы имеем дело также с обеспечением доступа индивида к различным социальным сервисам, только весьма ограниченный внутри организации. Функции, связанные с индивидуальным взаимодействием и поддержкой, реализуются в рамках психолого-педагогического сопровождения, т.е. ключевую позицию в сопровождении осуществляет тьютор, в задачи которого в том числе входит активизация механизмов социального сопровождения на основе тех ресурсов, которым располагает образовательная организация. Исследователи рассматривают комплексное сопровождение и в его структуре социальное сопровождение, как инструменты работы со студентамиинвалидами в контексте инклюзивного подхода, поэтому следует отметить, что социальное сопровождение в данном случае призвано помочь человеку преодолеть социальную эксклюзию.

Разнообразие трактовок термина «социальное сопровождение» и использование его в различных социально-гуманитарных контекстах нуждается в не- 
обходимости проведения анализа теоретических подходов в определении значения и применении данной категории с точки зрения социологической науки. Анализ современных исследований, непосредственно или косвенно посвященных изучению категории «социальное сопровождение», позволяет выделить следующие подходы в его определении: системный и активистско-деятельностный, теории социального обмена и социального конструкционизма.

Системный подход Т. Парсонса [3, с. 78-79], Н. Лумана [4, с. 207-209] позволит уточнить содержание социального сопровождения как самостоятельной системы и выявить его ключевые элементы, разнородные по своему характеру элементы, между которыми устанавливаются различные отношения и связи как вертикальные, т.е. между различными иерархическими уровнями, так и горизонтальные между элементами одного порядка или внутри элементов, представляющих собой подсистемы социального сопровождения. В свою очередь социальное сопровождение входит в более крупную систему социального обслуживания населения.

Важно подчеркнуть особую значимость рассмотрения социального сопровождения через призму системного подхода, которая заключается в том, что системный анализ данного процесса позволяет увидеть то, каким образом функционирует социальное сопровождение внутри более крупных систем в обществе. Помимо этого, с помощью системного подхода можно проанализировать иерархию организации социального сопровождения, а также выявить особый тип отношений и взаимосвязей внутри системы социального сопровождения, который позволяет реализовать ее специфические цели.

Так, о необходимости исследования социального сопровождения с позиций системного подхода пишет О.В. Заяц, которая систему социального сопровождения рассматривает как взаимосвязь отдельных элементов, что, по ее мнению, обеспечивает целостность исследования данной категории. Существующие правовые, организационные и экономические основы социального сопровождения, по мнению О.В. Заяц, позволяют рассматривать функционирование и взаимодействие различных организаций как систему [5, с. 10].

Социальное сопровождение может быть рассмотрено и как множество взаимосвязанных элементов. Основными элементами в этой системы являются службы социальных участковых, которые выполняют различные задачи в целях осуществления процесса социального сопровождения. Помимо указанных элементов систему образуют учреждения и организации местного самоуправления, а также индивид, группа, общность.

Примечательно, что в современной литературе социальное сопровождение рассматривается не только как отдельная система, но и как подсистема, ориентированная на профилактику сложной жизненной ситуации у индивида или семьи. Кроме того, оказывается помощь в преодолении ситуации социальной эксклюзии, как одна из миссий социального сопровождения, подчеркивается в исследовании 
А.Г. Скоробогатовой о социальном сопровождении пожилых людей [6, с. 137]. В данном случае предполагается, что службы социального сопровождения компенсируют социальное внимание к клиенту, которое объективно снижается и провоцирует социальную изоляцию пожилых, а также позволяют осуществлять мониторинг состояния и самочувствия пожилых людей. Социальное сопровождение, по мнению А.Г. Скоробогатовой, должно встраиваться в систему долговременного ухода за пожилыми людьми. Таким образом, социальное сопровождение может быть представлено элементом комплексной системы помощи определенной категории граждан, в рамках которых решаются задачи выявления и учета нуждающихся в помощи индивидов и включения их в социум.

Активистско-деятельностный подход (П. Бурдье, Э. Гидденс, Ю. Хабермас [7, с. 19], П. Штомпка [8, с. 325]) объясняет значение и сущность социального сопровождения в современном обществе, где оно призвано преобразовать социальные условия. Как деятельность социальное сопровождение не только внутренне упорядочена и структурирована, но и носит характер координирования и управления. В контексте активистско-деятельностного подхода социальное сопровождение может быть рассмотрено в качестве согласованной системы действий социальных акторов, поддерживающих и конструктивно изменяющих социальный порядок совместной деятельности в контексте данной культурной среды [9, с. 41]. Социальное сопровождение обладает структурными характеристиками деятельности. М.С. Каз представляет структуру деятельности следующим образом: субъект деятельности (причина активности); объект деятельности (предмет, на который направлена активность). Деятельность может происходить разновекторно: по линии субъект - объект $(\mathrm{C}-\mathrm{O})$ либо по линии субъект - субъект $(\mathrm{C}-\mathrm{C})$. Кроме того, возможны еще два типа ситуаций деятельности: С - СО (субъективация объекта), С - ОС (объективация субъекта). Субъект-объектная деятельность представляет собой «совокупность действий и операций»; субъект-субъектная - «взаимоотношения индивидов в процессе труда»; субъективация объекта - «принятие решений с учетом ценностных ориентаций, жизненных смыслов»; объективации субъекта «соответствует процесс овеществления деятельности субъекта в материальных и духовных результатах, являющихся предметным воплощением ценностных идеалов, а также процесс формирования групповых ценностей» [10, с. 26].

Социальное сопровождение может быть рассмотрено как вид социальной практики. Е.А. Старикова определяет в данном аспекте для социального сопровождения следующие характеристики. С позиций концепции социального действия социальное сопровождение можно отнести к целенаправленному действию, где целью выступает создание условий, способствующих мобилизации человека на активизацию скрытых ресурсов и его способности самостоятельно справляться с возникающими у него проблемами. В контексте нормативности социальное сопровождение является социальной практикой, в которой отношения между специа- 
листом и клиентом выстраиваются одновременно субъект-субъектной и субъектобъектной моделями. Также Е.А. Старикова отмечает такие свойства социального сопровождения, как воспроизводимость и тиражируемость [11, с. 218].

Таким образом, данный автор подчеркивает деятельностную сущность социального сопровождения именно в виде социальной практики (вида социального действия), а не только технологий, методов и способов социальной помощи. Мы разделяем такую точку зрения, так как социальное сопровождение, обладая целевыми установками, широко распространено в современной практике деятельности социальных служб, включает в процесс своей реализации индивидов и позволяет объекту воздействия усвоить социальные и культурные нормы использования социальных сервисов, решения социальных конфликтов и противоречий, преодоления социальных трудностей, а также социального взаимодействия с другими индивидами и структурами.

В современной литературе есть более узкое представление социального сопровождения в контексте деятельностной концепции. К.В. Минина рассматривает социальное сопровождение как комплексную технологию помощи, исследуя вопросы решения проблемы дезадаптации подростков. По мнению автора, такую технологию составляют следующие элементы: диагностика социального неблагополучия, индивидуальная и групповая работа, профилактика риска возникновения социальных патологий, повышение компетентности специалистов, осуществляющих сопровождение; обеспечение кадров специфическими технологиями работы в рамках сопровождения [12, с. 129]. На наш взгляд, подобная трактовка категории «социальное сопровождение» позволяет уточнить лишь один из аспектов социального сопровождения, связанный с управляемым достижением результата технологического воздействия, реализуемого в определенный период.

Вместе с тем в трудах современных авторов мы находим еще более узкое представление о социальном сопровождении. М.Б. Лига, И.А. Щеткина, Е.Ю. Захарова [13, с. 69] характеризуют социальное сопровождение в рамках деятельностного подхода. В то же время оно представлено как форма выражения социального сопровождения как деятельности, а именно - в виде социальной услуги. Рассматривая социальное сопровождение применительно к решению проблем инвалидов, они отмечают, что «социальное сопровождение является услугой по включению инвалидов в современный социум». В своем определении авторы отталкиваются от понимания социальной услуги на основе Федерального закона от 28.12.2013 № 442-Ф3 (ред. от 01.05.2019) «Об основах социального обслуживания граждан в Российской Федерации», где под социальной услугой действие или действия в сфере социального обслуживания по оказанию постоянной, периодической, разовой помощи, в том числе срочной помощи, гражданину в целях улучшения условий его жизнедеятельности и (или) расширения его возможностей самостоятельно обеспечивать свои основные жизненные потребности. По нашему мнению, невозможно све- 
сти социальное сопровождение к отдельному действию, а значит, и к социальной услуге, так как это, как минимум, совокупность действий, которые на сегодняшний день не ограничиваются лишь сферой социального обслуживания. Социальное сопровождение в режиме деятельности требует от специалистов активизации механизмов помощи и определения ресурсов в различных жизненных сферах общества (медицинское обслуживание, образование, социальная защита, жилищно-коммунальное обслуживание, сфера занятости и др.). Кроме того, социальное сопровождение ориентировано на индивидуальный запрос индивида или семьи, что позволяет выйти за рамки нормативно определенных объемов, времени и периодичности оказания помощи, как это заложено в предоставлении той или иной социальной услуги.

Социальное сопровождение может быть проанализировано с позиций исследования социальной реальности, так как в процессе взаимоотношений между сопровождающим и сопровождаемым, а также иными участниками этого процесса конструируется определенный вид социальной реальности, в котором создаются необходимые и благоприятные условия для урегулирования проблем индивида или семьи. В контексте социального конструкционизма в социологии с позиций М. Вебера социальное сопровождение может быть рассмотрено как совокупность действий индивидов, а значит, может быть проанализировано как вид социальной реальности [14, с. 602]. Социальное сопровождение основывается на межсубъектном взаимодействии, что также формирует социальную реальность в контексте феноменологического подхода А. Шюца $[15$, с. 529]. Анализ социального сопровождения на основе конструирования социальной реальности позволяет выделять его виды, формы и уровни, что дает основание говорить о наличии определенной конструируемой структуры социального сопровождения (Э. Гидденс [16, с. 215], П. Сорокин [17, с. 92]). Основываясь на представлении о сущности социальной реальности П. Бергера и Т. Лукмана [18, с. 42], следует отметить, что конструирование социального сопровождения происходит в процессе взаимодействия социальной службы и клиента, коммуникации специалиста и клиента. В процессе коммуникации субъекты транслируют свои цели, которые формируют и цели социального сопровождения, действия и поведение субъектов в процессе социального сопровождения опосредованно их потребностям. На результат социального сопровождения оказывает влияние язык, используемый субъектами взаимодействия, так как именно с помощью этого инструмента происходит конструирование социальной реальности социального сопровождения.

Нам импонирует точка зрения авторов И.К. Свищева, Т.Н. Конева, которые, исследуя понятие «сопровождение инвалидов», делают обобщение различных трактовок данного понятия и выделяют ряд ключевых признаков:

1) сопровождение дает возможность инвалиду выбирать и действовать по собственному усмотрению; 
2) сопровождение предоставляет возможность научиться новым типам поведения и способствует личностному развитию;

3) сопровождение акцентирует ответственность и самостоятельность клиента, а организатору сопровождения отводится функция по созданию условий, которые будут стимулировать клиента на изменение своей ситуации. В результате авторы определяют сопровождение как систему мер, направленных на поддержание процессов активной жизнедеятельности и развитие естественных способностей инвалидов, на создание условий для предупреждения развития негативных последствий возникающих социальных проблем, мобилизацию и активизацию скрытых резервов, на обучение новым или доступным профессиям, развитие способности самостоятельно справляться с возникающими проблемами [19, с. 268].

В данном подходе сопровождение представлено в виде системы, в которой индивид, совершая самостоятельные действия по изменению своего положения, находится в квазисоциальном пространстве, которое конструируется службой сопровождения и специалистами, для оперативного оказания индивиду помощи, в случае, если она сталкивается с какими-либо трудностями или барьерами. Конструирование социального пространства, в котором индивид будет решать свои проблемы, происходит на основе его индивидуальных потребностей и особенностей социального опыта.

Социальное сопровождение предполагает многоаспектное и многоуровневое социальное взаимодействие. Но в центре внимания, безусловно, находится социальное взаимодействие между клиентом и субъектом оказания помощи. Теория обмена Дж. Хоманса [20, с. 86] позволяет одновременно проанализировать источники депривации индивида или семьи, получающих помощь и содействие в процессе социального сопровождения, и изучить механизм социального взаимодействия, который складывается в рамках социального сопровождения. Кроме изучения межличностных мотивов и установок социального взаимодействия в процессе социального сопровождения очевидна необходимость исследования механизмов обмена социального сопровождения на уровне организаций и социальных структур, поскольку результат социального сопровождения во многом зависит от успеха взаимодействия на данном уровне, поэтому представляет интерес возможность экстраполяции законов обмена по П. Блау [21, с. 11] на исследование социального взаимодействия в рамках социального сопровождения.

На примере деятельности службы сопровождения инвалидов и семей с детьми-инвалидами и детьми с ограниченными возможностями О.В. Бейгуленко и Ю.А. Ардашова [22, с. 120-121] выделяют основные признаки социального сопровождения:

- деятельность на закрепленных территориях;

- социальное сопровождение реализуется междисциплинарной бригадой специалистов, где ключевая роль отведена участковому специалисту по социальной работе; 
- сопровождение реализуется на основе заранее разработанной программы сопровождения.

Примечательно, что авторы подчеркивают особенную роль участкового специалиста по социальной работе в процессе социального сопровождения и очерчивают круг его ключевых функций:

1) координирование службы сопровождения;

2) организация деятельности по сопровождению;

3) установление внутриотраслевого, межведомственного и межсекторного взаимодействия;

4) ведение электронной базы данных по социальному сопровождению;

5) оформление и управление реализацией программ сопровождения, а также мониторинг ее результатов.

В обозначенном подходе социальное сопровождение выходит за рамки индивидуального взаимодействия, и что ценно, на наш взгляд, авторы подчеркивают, что в данном случае осуществляются разные формы социального взаимодействия: внутриотраслевое, межведомственное и межсекторное. Но следует подчеркнуть, что центральное место в социальном сопровождении занимает индивидуальное взаимодействие, на основе которого клиент или семья могут получить не только доступ к социальным сервисам на территории, но и индивидуальную помощь и поддержку, в результате которой формируется уверенность в своих действиях и происходит процесс социального научения, содействующий усвоению необходимых социальных норм и образцов поведения.

Анализируя социальное сопровождение инвалидов на примере данной деятельности в Забайкальском крае, О.В. Бейгуленко и Ю.А. Ардашова пришли к выводу о том, что социальное сопровождение - это «комплекс мероприятий, направленных на содействие инвалидам в преодолении трудной жизненной ситуации, который способствует повышению качества социальной работы с населением» [22, с. 122]. В данном случае, по нашему мнению, сложно разграничить другие виды помощи (социальная реабилитация) и социальное сопровождение, но вместе с тем ключевым ориентиром в необходимости организации социального сопровождения авторы видят трудную жизненную ситуацию у населения.

Обзор источников, посвященных социологическому исследованию понятия и содержания категории «социальное сопровождение», позволяет выделить следующие типы социального сопровождения:

1. Социальное сопровождение граждан в обществе - система постоянной нормативно определенной и поддерживаемой государством деятельности, направленной на восстановление социального статуса и социального функционирования граждан в обществе, поиск и оптимизацию собственных ресурсов граждан и ресурсов общества для предупреждения и разрешения трудных жизненных ситуаций. 
2. Социальное сопровождение в системе оказания помощи отдельным категориям граждан или в конкретных жизненных ситуациях - организация комплексной проблемно-ориентированной деятельности субъектов социальной помощи, направленной на создание условий для оперативного устранения факторов риска и кризисных явлений в жизни индивида или семьи.

3. Социальное сопровождение индивида или семьи в организации - совокупность действий специалистов организации по снижению или устранению социальных рисков в жизнедеятельности индивида или семьи с целью обеспечения благоприятных условий для достижения общих целей взаимодействия с организацией (получение образования, медико-социальная реабилитация, коррекция поведения и т.д.).

Экстраполируя ранее рассмотренные социологические концепции на данные типы социального сопровождения, можно провести анализ сущности социального сопровождения (таблица).

Таким образом, социальное сопровождение граждан в обществе предполагает наличие нормативно-правовых условий для его реализации, охватывает все категории и группы населения ориентированно и подчиняется целям социальной политики государства, но не исключает при этом частно-государственного социального партнерства в процессе поиска и формирования необходимых ресурсов для оказания помощи индивидам или семьям. Социальное сопровождение в системе оказания помощи отдельным категориям граждан или в конкретных жизненных ситуациях имеет четко определенные цели по решению, как правило, острых проблем и/или устранению кризисных явлений в жизни индивида или семьи. Ключевая задача социального сопровождения в данном случае заключается в создании социально безопасной директории для действий различных специалистов и организаций, а также поведения индивида или семьи, что позволит оперативно, с минимальными издержками для сопровождаемого (-ых) и общества разрешить проблемы или преодолеть трудную жизненную ситуацию. Социальное сопровождение индивида или семьи в организации (образовательной, медицинской, социальной службы) является элементом совокупности ее деятельности, направленной на удовлетворение потребностей индивида или семьи и соответствующей целям их сотрудничества. Здесь социальное сопровождение выполняет обеспечительную и защитную функцию, содержание которой, в целом, заключается в создании условий для того, чтобы те или иные социальные риски не могли стать барьером для достижения целей сотрудничества индивида или семьи с организацией.

Социальное сопровождение граждан в обществе инициировано государством и реализуется через государственные органы управления и службы в сфере социальной защиты и социального обслуживания. Социальное сопровождение в системе оказания помощи отдельным категориям граждан или в конкретных жизненных условиях находит свое отражение как в государственном, так и негосударственном секторах социальной работы с населением (например, социальное 


\section{Анализ сущности социального сопровождения}

\section{в контексте социологических подходов}

\begin{tabular}{|c|c|c|c|}
\hline \multirow[b]{2}{*}{$\begin{array}{c}\text { Вид } \\
\text { социологического } \\
\text { подхода, авторы }\end{array}$} & \multicolumn{3}{|c|}{ Типы социального сопровождения } \\
\hline & $\begin{array}{c}\text { Социальное } \\
\text { сопровождение } \\
\text { граждан в обществе }\end{array}$ & $\begin{array}{c}\text { Социальное } \\
\text { сопровождение в системе } \\
\text { оказания помощи } \\
\text { отдельным категориям } \\
\text { граждан или в конкретных } \\
\text { жизненных условиях } \\
\end{array}$ & $\begin{array}{c}\text { Социальное } \\
\text { сопровождение } \\
\text { индивида или семьи } \\
\text { в организации }\end{array}$ \\
\hline $\begin{array}{l}\text { Системный подход: } \\
\text { Т. Парсонс, } \\
\text { Н. Луман }\end{array}$ & $\begin{array}{l}\text { Направлено на создание } \\
\text { условий для включения } \\
\text { индивида или семьи в об- } \\
\text { щество, восстановление их } \\
\text { конструктивного социаль- } \\
\text { ного функционирования }\end{array}$ & $\begin{array}{l}\text { Сущность заключается } \\
\text { в системно организо- } \\
\text { ванных мероприятий и } \\
\text { вмешательств, которые } \\
\text { ориентированы на } \\
\text { снижение остроты или } \\
\text { устранения проблемы } \\
\text { индивида или семьи }\end{array}$ & $\begin{array}{l}\text { Представляет собой } \\
\text { систему действий раз- } \\
\text { личных специалистов, } \\
\text { направленных на уст- } \\
\text { ранение социальных } \\
\text { рисков и неблагопри- } \\
\text { ятных социальных } \\
\text { факторов, препятст- } \\
\text { вующих достижению } \\
\text { целей взаимодействия } \\
\text { индивида или семьи с } \\
\text { организацией } \\
\end{array}$ \\
\hline $\begin{array}{l}\text { Активистско- } \\
\text { деятельностный } \\
\text { подход: } \\
\text { Бурдье, } \\
\text { Э. Гидденс, } \\
\text { Ю. Хабермас, } \\
\text { П. Штомпка } \\
\end{array}$ & $\begin{array}{l}\text { Представляет собой орга- } \\
\text { низованную совместную } \\
\text { деятельность различных } \\
\text { социальных структур и } \\
\text { индивида или семьи }\end{array}$ & $\begin{array}{l}\text { Отождествляется с } \\
\text { технологией помощи } \\
\text { индивиду или семье } \\
\text { для решения конкрет- } \\
\text { ных проблем }\end{array}$ & $\begin{array}{l}\text { Подразумевает совме- } \\
\text { стные действия спе- } \\
\text { циалистов, согласован- } \\
\text { ные с целями и задача- } \\
\text { ми взаимодействия } \\
\text { организации с индиви- } \\
\text { дом или семьей } \\
\end{array}$ \\
\hline $\begin{array}{l}\text { Теория социального } \\
\text { конструкционизма: } \\
\text { М. Вебер, } \\
\text { А. Щюц, } \\
\text { Э. Гидденс, } \\
\text { П. Сорокин, } \\
\text { П. Бергер, } \\
\text { Т. Лукман }\end{array}$ & $\begin{array}{l}\text { Подразумевает сконст- } \\
\text { руированную в процессе } \\
\text { взаимодействия систему } \\
\text { социальных сервисов для } \\
\text { индивидов или семей по } \\
\text { предупреждению возник- } \\
\text { новения и разрешению } \\
\text { трудных жизненных си- } \\
\text { туаций }\end{array}$ & $\begin{array}{l}\text { В центре внимания } \\
\text { находится процесс } \\
\text { программирования и } \\
\text { управления действия- } \\
\text { ми и способами вме- } \\
\text { шательства различных } \\
\text { компетентных органи- } \\
\text { заций с целью опера- } \\
\text { тивного решения кон- } \\
\text { кретных проблем ин- } \\
\text { дивида или семьи } \\
\end{array}$ & $\begin{array}{l}\text { Заключается в построе- } \\
\text { нии маршрутов «движе- } \\
\text { ния» индивида или се- } \\
\text { мьи к достижению це- } \\
\text { лей взаимодействия с } \\
\text { организацией, на усло- } \\
\text { виях исключения или } \\
\text { снижения влияния соци- } \\
\text { альных рисков }\end{array}$ \\
\hline $\begin{array}{l}\text { Теория социального } \\
\text { обмена: } \\
\text { Дж. Хоманс }\end{array}$ & $\begin{array}{l}\text { Представляет собой мно- } \\
\text { гоуровневое взаимодейст- } \\
\text { вие субъекта сопровожде- } \\
\text { ния с индивидом или семь- } \\
\text { ей, а также в их интересах, } \\
\text { включая индивидуальное } \\
\text { взаимодействие, межпро- } \\
\text { фессиональное, межведом- } \\
\text { ственное и межсекторное } \\
\text { взаимодействие }\end{array}$ & $\begin{array}{l}\text { Выражается в структу- } \\
\text { рированном взаимодей- } \\
\text { ствии между субъектом } \\
\text { взаимодействия и инди- } \\
\text { видом или семьей в } \\
\text { целях решение конкрет- } \\
\text { ных проблем, где } \\
\text { стержнем для организа- } \\
\text { ции коммуникации яв- } \\
\text { ляются кейс-технологии }\end{array}$ & $\begin{array}{l}\text { Сконцентрировано на } \\
\text { индивидуальном взаи- } \\
\text { модействии субъекта и } \\
\text { индивида или семьи, где } \\
\text { основное место отво- } \\
\text { дится мотивированию, } \\
\text { моральной поддержке и } \\
\text { организации помогаю- } \\
\text { щей коммуникации }\end{array}$ \\
\hline
\end{tabular}

сопровождение женщин-жертв домашнего насилия, социальное сопровождение лиц без определенного места жительства, социальное сопровождение лиц, живущих с ВИЧ, и т.д.). Социальное сопровождение индивида или семьи в органи- 
зации в большей степени сегодня представлено в деятельности образовательных организаций разных уровней (дошкольные, школьные образовательные учреждения, организации среднего профессионального и высшего образования), а также в медицинских организациях (медико-социальная помощь лицам с инвалидностью, медико-социальное сопровождение новорожденных, детей из семей в социально опасном положении и др.).

В заключение представленного анализа можно отметить следующее:

1. Социальное сопровождение представляет собой систему деятельности прежде всего на основе междисциплинарного подхода, которую нельзя сводить только к технологии работы по достижению конкретных изменений объекта воздействия.

2. С позиции социологического анализа социальное сопровождение не подразумевает прохождение маршрута конструктивных изменений непосредственно вместе с сопровождаемым, одна из его прагматических задач заключается в создании структурных, институциональных условий для самостоятельного «движения» индивида по пути разрешения своих трудностей.

3. Социальное сопровождение позволяет восстановить функционирование индивида или семьи на нескольких уровнях взаимодействия, последовательно задействовав все ресурсы сопровождаемого и социальной структуры.

4. Социальное сопровождение позволяет не только сконцентрировать внимание на формировании социально необходимых навыков и удовлетворении потребностей индивида или семьи, но и предотвратить их социальную исключенность и стигматизацию в обществе, расширить доступ к возможностям и ресурсам, которыми располагает социальная структура на местном уровне.

5. Социальное сопровождение не только конструируется на основе совокупности проблем и потребностей индивида или семьи, но и позволяет выйти за рамки «государственной опеки», сформировать свой собственный конструктивный опыт взаимодействия с социумом и выстроить сбалансированные, экологически устойчивые взаимоотношения с другими элементами социальной системы.

\section{Список литературы}

1. Холостова Е.И., Климантова Г.И. Энциклопедия социальных практик поддержки семьи и детства в Российской Федерации. - М.: Дашков и К, 2014. -752 c.

2. Сизикова В.В., Тюрина Н.А. Система сопровождения абитуриентов и студентов вузов в условиях инклюзивного образования // Ученые записки РГСУ. - 2012. - № 8 (108). - С. 104-107.

3. Парсонс Т. О социальных системах. - М.: Академический проспект, 2002. -832 c. 
4. Луман Н. Теория общества // Теория общества: сб.: пер. с нем. англ. / сост. и общ. ред. А.Ф. Филиппова. - М.: Канон-Пресс-Ц, 1999. - С. 196-235.

5. Заяц О.В., Панкова Н.В. Системный подход к организации социального сопровождения семьи (на примере Приморского края) // Current issues of social researches and social work: Materials of the III international scientific conference. Prague, 2017. - C. 9-15.

6. Скоробогатова А.Г. Социальное сопровождение пожилых людей 80+ // Социология. - 2019. - № 3. - С. 135-138.

7. Современная социальная теория: Бурдье, Гидденс, Хаберманс / сост. и пер. А.В. Леденевой. - Новосибирск: Изд-во НовГУ, 1995. - 120 с.

8. Штомпка П. Социология социальных изменений: пер. с англ. / под ред. В.А. Ядова. - М.: Аспект Пресс, 1996. - 416 с.

9. Тихонов А.В. От социологии менеджмента к социологии управления // Социологические исследования. - 2011. - № 2. - С. 40-45.

10. Каз М.С. Динамика экономического знания и мотивация труда: когнитивно-ценностный подход. - Томск: Изд-во Том. гос. ун-та, 2003. - 351 с.

11. Старикова Е.А. В поисках истоков формирования социального сопровождения как социальной практики // Социология. - 2017. - № 4. - С. 215-219.

12. Минина К.В. Технологии социального сопровождения дезадаптированных подростков (подростков группы риска) в условиях образовательного учреждения открытой (сменной) школы // Ученые записки Санкт-Петербургского государственного института психологии и социальной работы. - 2008. T. 10, № 2. - С. 127-133.

13. Лига М.Б., Щеткина И.А., Захарова Е.Ю. Социальное сопровождение лиц с ограниченными возможностями здоровья как социальная услуга // Общетеоретические и отраслевые проблемы науки и пути их решения. - Калуга, 2019. - С. 67-70.

14. Вебер М. Основные социологические понятия / пер. с нем. М.И. Левиной // Вебер М. Избранные произведения. - М.: Прогресс, 1990. - 808 с.

15. Шюц А. Формирование понятия и теории в общественных науках // Американская социологическая мысль: Тексты / под ред. В.И. Добренькова; Межд. ун-т бизнеса и упр. - М., 1996. - С. 526-541.

16. Гидденс Э. Социология. - М.: Эдиториал УРСС, 1999. - 704 с.

17. Сорокин П. Человек, цивилизация, общество. - М.: Политиздат, 1992. -298 c.

18. Бергер П., Лукман Т. Социальное конструирование реальности. Трактат по социологии знания / пер. с англ. Е.Д. Руткевич. - М.: Медиум, 1995. - 323 с.

19. Свищева И.К., Конева Т.Н. Социальное сопровождение как ресурс повышения интеграционного потенциала инвалида // Изв. Сарат. ун-та. Новая серия. Социология. Политология. - 2018. - № 3. - С. 265-268.

20. Хоманс Дж. Социальное поведение как обмен // Современная зарубежная социальная психология. - М.: Изд-во МГУ, 1984. - С. 82-91. 
21. Блау П. Различные точки зрения на социальную структуру и их общий знаменатель // Американская социологическая мысль. - М.: Изд-во Моск. ун-та, 1994. - С. 8-29.

22. Бейгуленко О.В., Ардашова Ю.И. Социальное сопровождение инвалидов в Забайкальском крае // Ученые записки ЗабГУ. Философия, социология, культурология, социальная работа. - 2015. - № 4 (63). - С. 116-123.

\section{References}

1. Kholostova E.I., Klimantova G.I. Entsiklopediia sotsial'nykh praktik podderzhki sem'i i detstva v Rossiiskoi Federatsii [Encyclopedia of social practices to support family and childhood in the Russian Federation]. Moscow, Dashkov i K, 2014, $752 \mathrm{p}$.

2. Sizikova V.V., Tiurina N.A. Sistema soprovozhdeniia abiturientov i studentov vuzov $\mathrm{v}$ usloviiakh inkliuzivnogo obrazovaniia [The system of accompanying university entrants and students in the context of inclusive education]. Uchenye zapiski RGSU, 2012, no. 8 (108), pp. 104-107.

3. Parsons T. The social systems (Russ. ed.: Parsons T. O sotsial'nykh sistemakh. Moscow, Akademicheskii prospect, 2002, 832 p.).

4. Luhmann N. Theorie der Gesellschaft (Russ. ed.: Luman N. Teoriia obshchestva, Moscow, Kanon-Press-Ts, 1999, pp. 196-235).

5. Zaiats O.V., Pankova N.V. Sistemnyi podkhod k organizatsii sotsial'nogo soprovozhdeniia sem'i (na primere Primorskogo kraia) [A systematic approach to the organization of social support for the family (on the example of Primorsky Krai)]. Current issues of social researches and social work, 2017, pp. 9-15.

6. Skorobogatova A.G. Sotsial'noe soprovozhdenie pozhilykh liudei $80+$ [Social support for elderly people 80+]. Sotsiologiia, 2019, no. 3, pp. 135 - 138.

7. Bourdieu P., Giddens A., Habermas J. Modern social theory (Russ. ed.: Burd'e P., Giddens A., Khabermas J. Sovremennaia sotsial'naia teoriia. Novosibirsk, Yaroslav-the-Wise Novgorod State University, 1995, 120 p.).

8. Sztompka P. The sociology of social change (Russ. ed.: Shtompka, P. Sotsiologiia sotsial'nykh izmenenii. Moscow, Aspekt Press, 1996, 416 p.).

9. Tikhonov A.V. Ot sotsiologii menedzhmenta $\mathrm{k}$ sotsiologii upravleniia [From the sociology of management to the sociology of supervision]. Sotsiologicheskie issledovaniia, 2011, no. 2, pp. 40-45.

10. Kaz M.S. Dinamika ekonomicheskogo znaniia i motivatsiia truda: kognitivnotsennostnyi podkhod [The dynamics of economic knowledge and labor motivation: a cognitive-value approach]. Tomsk, Tomsk State University, 2003, 351 p.

11. Starikova E.A. V poiskakh istokov formirovaniia sotsial'nogo soprovozhdeniia kak sotsial'noi praktiki [In search of sources of formation of social maintenance as social practice]. Sotsiologiia, 2017, no. 4, pp. $215-219$. 
12. Minina K.V. Tekhnologii sotsial'nogo soprovozhdeniia dezadaptirovannykh podrostkov (podrostkov gruppy riska) v usloviiakh obrazovatel'nogo uchrezhdeniia otkrytoi (smennoi) shkoly [Technologies of social support for maladjusted adolescents (adolescents at risk) in an educational institution of an open (shift-type) school]. Uchenye zapiski Sankt--Peterburgskogo gosudarstvennogo instituta psikhologii $i$ sotsial'noi raboty, 2008, no. 2, vol. 10, pp. 127-133.

13. Liga M.B., Shchetkina I. A., Zakharova E.Iu. Sotsial'noe soprovozhdenie lits s ogranichennymi vozmozhnostiami zdorov'ia kak sotsial'naia usluga [Social support of persons with disabilities as a social service]. Obshcheteoreticheskie $i$ otraslevye problemy nauki i puti ikh resheniia, 2019, pp. 67-70.

14. Weber M. Soziologische Grundbegriffe (Russ. ed.: Veber M. Osnovnye sotsiologicheskie poniatiia. Moscow, Progress, 1990, 808 p.).

15. Schütz A. Der sinnhafte Aufbau der sozialen Welt. Eine Einleitung in die verstehende Soziologie (Russ. ed.: Shiuts A. Formirovanie poniatiia i teorii v obshchestvennykh naukakh. Moscow, International University of Business and Management, 1996, pp. 526-541.).

16. Giddens A. Sociology (Russ. ed.: Giddens E. Sotsiologiia. Moscow, Editorial URSS, 1999, 704 p.).

17. Sorokin P. Chelovek, tsivilizatsiia, obshchestvo [Human, civilization, society]. Moscow, Politizdat, 1992, 298 p.

18. Berger P., Luckman T. Die gesellschaftliche Konstruktion der Wirklichkeit (Russ. ed.: Berger P., Lukman T. Sotsial'noe konstruirovanie real'nosti. Traktat po sotsiologii znaniia. Moscow, Medium, 1995, 323 p.).

19. Svishcheva I.K, Koneva T.N. Sotsial'noe soprovozhdenie kak resurs povysheniia integratsionnogo potentsiala invalida [Social escort as the resource of an increase in the integrated potential of disabled people]. Izvestiia Saratovskogo universiteta. Novaia seriia. Seriia Sotsiologiia. Politologiia, 2018, no. 3, pp. 265-268.

20. Homans G. Social behavior as exchange (Russ. ed.: Khomans Dzh. Sotsial'noe povedenie kak obmen. Sovremennaia zarubezhnaia sotsial'naia psikhologiia, Moscow, MSU, 1984, pp. 82-91).

21. Blau P. Different perspectives on social structure and their common denominator (Russ. ed.: Blau P. Razlichnye tochki zreniia na sotsial'nuiu strukturu i ikh obshchii znamenatel'. Amerikanskaia sotsiologicheskaia mysl'. Moscow, MSU, 1994, pp. 8-29).

22. Beigulenko O.V., Ardashova Iu.I. Sotsial'noe soprovozhdenie invalidov v Zabaikal'skom krae [Social support for disabled people in the Zabaikal'sky krai]. Uchenye zapiski ZabGU. Seriia: Filosofiia, sotsiologiia, kul'turologiia, sotsial'naia rabota, 2015, no. 4 (63), pp. 116-123.

Оригинальность $83 \%$

Получено 24.12.2020 Принято 11.01.2021 Опубликовано 31.03.2021 


\section{G.A. Telegina}

\section{THEORETICAL APPROACHES TO DEFINE THE CONCEPT OF SOCIAL SUPPORT IN SOCIOLOGY}

The article examines the notion of social support in the context of sociological concepts. At the same time, it should be noted that the need to consider a category is also due to its interdisciplinary status, since this definition is actively used by other scientific disciplines, such as psychology, pedagogy, etc. In sociology the concept of social support is often associated with the issues of providing social assistance to individuals and families in difficult life situations. In our opinion, the category of social support, from the standpoint of sociology, has a much more complex structure and semantic meaning. We examined its essence, relying on such classical approaches in sociology as systemic, activist-activity, the theory of social construction and the theory of exchange, all put in the modern context. At the same time, the works of other researchers were studied. The variety of views on the concept of social support found in the sociological literature let us distinguish three stands, namely: social support of citizens in society; social support in the system of providing assistance to certain categories of citizens or in specific living conditions; social support of an individual or family in an organization. We analyzed the content of this typology and identified the following criterion grounds: systemic characteristics, the impossibility of reducing to the technology of social assistance alone, the specifics of interaction between the supporters and the supported, acquiring social experience in the process of supporting, overcoming exclusion and providing access to the resources of the social system.

Keywords: social support, difficult life situation, activist-activity approach, system approach, theory of social constructionism, theory of social exchange.

Galina A. Telegina - Senior Lecturer, Department of Social Work and Conflictology, Perm State National Research University, e-mail: teleginagIn@yandex.ru.

Received 24.12.2020 Accepted 11.01.2021 Published 31.03.2021 